\title{
INFLUENCE OF THE SURFACE CONDITION ON THE ADHESION OF COMPOSITE MATERIALS TO ENAMEL
}

\begin{abstract}
This work presents a method of measuring the maximum stress that a composite sample fixed on a tooth surface will withstand. The test was carried out for 3 different surface conditions of enamel: no processing, after treatment with a diamond drill, and after treatment with a diode laser. The force of adhesion was measured in an Instron 5960 testing machine. The results demonstrate a significant effect of the surface condition on the adhesion of the composite to the enamel.
\end{abstract}

Keywords: strength machine, dental treatment, laser, drill

\section{INTRODUCTION}

Conservative dentistry is a dynamically developing field of medicine. Everyone dreams about healthy teeth and a nice smile. The role of dentists and the team working on the quality of dental materials is to make the most durable fillings, similar (especially in external appearance) to tooth enamel.

\section{AIM}

The purpose of the work was to determine the value of the maximum shear stress at which the composite material breaks away from the enamel. It is assumed that the condition of the tooth surface will affect the value of stress. The studies considered three surface conditions most frequently used by dentists:
a) enamel without treatment,
b) enamel after machining with a drill, and
c) enamel after laser treatment.

1 Corresponding author: Marta Szmyd, student, Rzeszow University of Technology, Powstancow Warszawy 8, 35-959 Rzeszow, Poland, e-mail: szm1@o2.pl

2 Dariusz Paliga, Rzeszów, Dental Practice

3 Andrzej Wasilewski, Rzeszow University of Technology, Powstancow Warszawy 8, 35-959 Rzeszow, Poland 


\section{IMPORTANT CONCEPTS}

Adhesion is the tendency of dissimilar particles or surfaces to cling to one another (cohesion refers to the tendency of similar or identical particles/surfaces to cling to one another)[1]. IUPAC definition of adhesion, it is the process of attachment of a substance to the surface of another substance

Maximum tangential stress - the adhesion force is the maximum tangential stress (force exerted on the surface) at which the composite loaded with shear force $\mathrm{F}$ will break away from the enamel surface.

We calculate the maximum tangential stress from the formula [2]:

$$
\tau_{\max }=\frac{F_{\max }}{S} \quad\left[\frac{N}{m^{2}}\right]
$$

$F_{\max }$ - maximum load at which the composite will break, $S$ - contact surface of the composite with the tooth.

\section{THE EXPERIMENTAL METHOD}

A tooth immersed in acrylic with a composite attached to the surface was placed in a testing machine. A load was applied to the composite sample.

Figure 1 shows a schematic of the experimental set up.

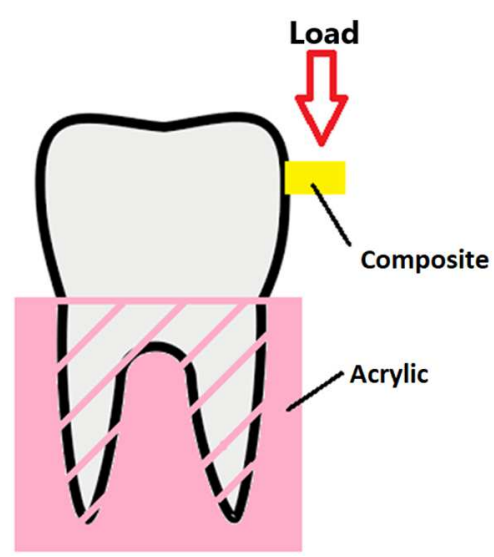

Fig. 1. Adhesion measurement scheme

\section{ENAMEL TREATMENT}

Drill processing

The first way used to process the enamel was to treat the surface with a drill. A diamond drill bit with a grain size of approx. $150 \mu \mathrm{m}$ was used. Diamond drills 
are made of high quality stainless steel which is covered with industrial diamond filings. Thanks to the advanced production technology of diamond drills, it is possible to obtain the desired granularity [3].

\section{Laser treatment}

During the experiment, the Lasotronix Smart M laser diode was used with a $0.2 \mathrm{~mm}$ optical tip.

Laser parameters:

a) wavelength $-980 \mathrm{~nm}$

b) power $-2 \mathrm{~W}$

c) operating mode - pulse mode, the duration of the pulse being equal to the duration of the interval between pulses and $100 \mu \mathrm{s}$

d) frequency $-5 \mathrm{kHz}$.

The beam of light was introduced in such a way that the optical fiber touched the surface of the tooth. Without removing the end of the optical fiber, the beam was moved linearly along the surface (surface contact technique). Thanks to this technique, power losses were avoided [4].

\section{IMAGE OF ENAMEL AFTER TREATMENT}

In order to compare the surface of the teeth after processing, they were viewed under a microscope. A scanning electron microscope (SEM) was used for observation.

The pictures show:

a) enamel without treatment (Fig. 2),

b) enamel surface after drill treatment (Fig. 3)

c) enamel surface after laser treatment (Fig. 4).

\section{Surface roughness of the enamel}

On the basis of the above images, we can conclude that enamel after treatment with a drill has a greater roughness. Therefore, the composite should better adhere to the enamel after being treated with the drill bit.

\section{MATERIALS AND EQUIPMENT USED IN THE EXPERIMENT}

Preparing for the experiment, special metal moulds were designed, which were later used to make a silicone cast - an acrylic mould and a composite mould. The necessary materials were purchased, such as a composite, an intermediate layer, phosphoric acid for etching the surface and materials for sample preparation. 


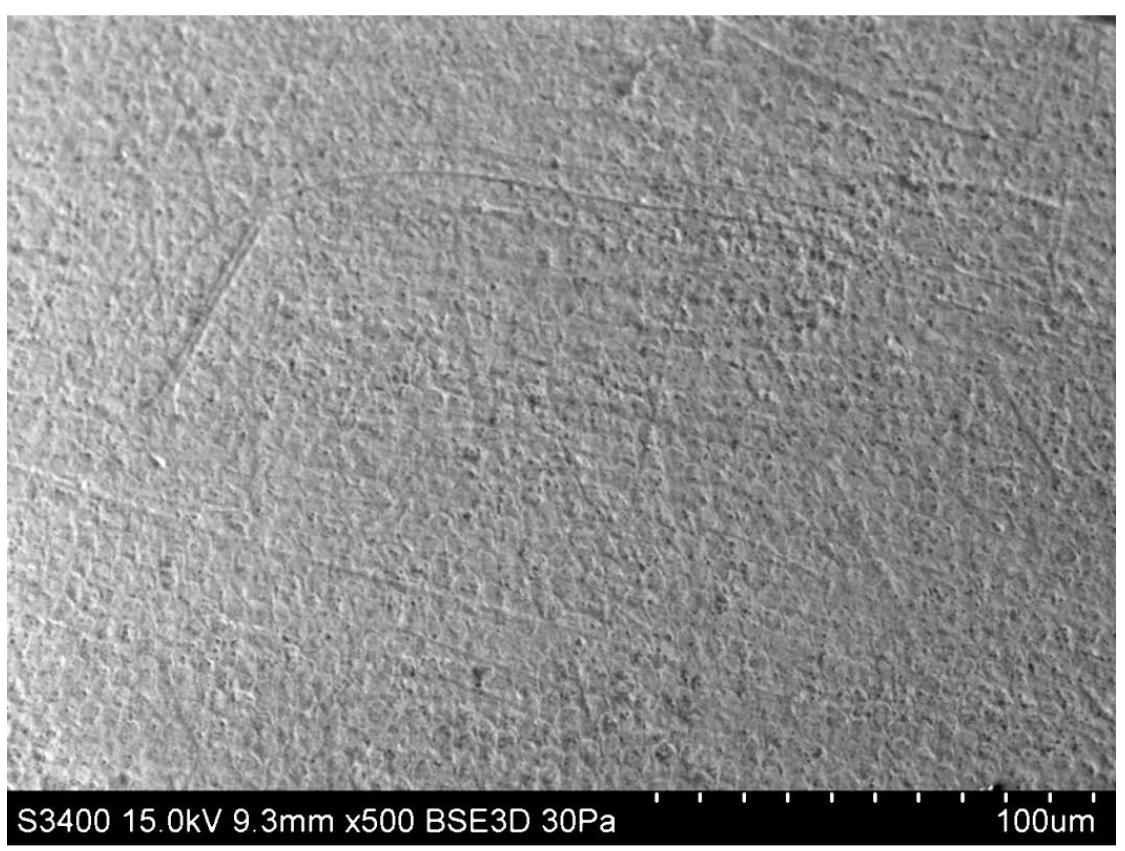

Fig. 2. Image of enamel without processing, magnification 500x

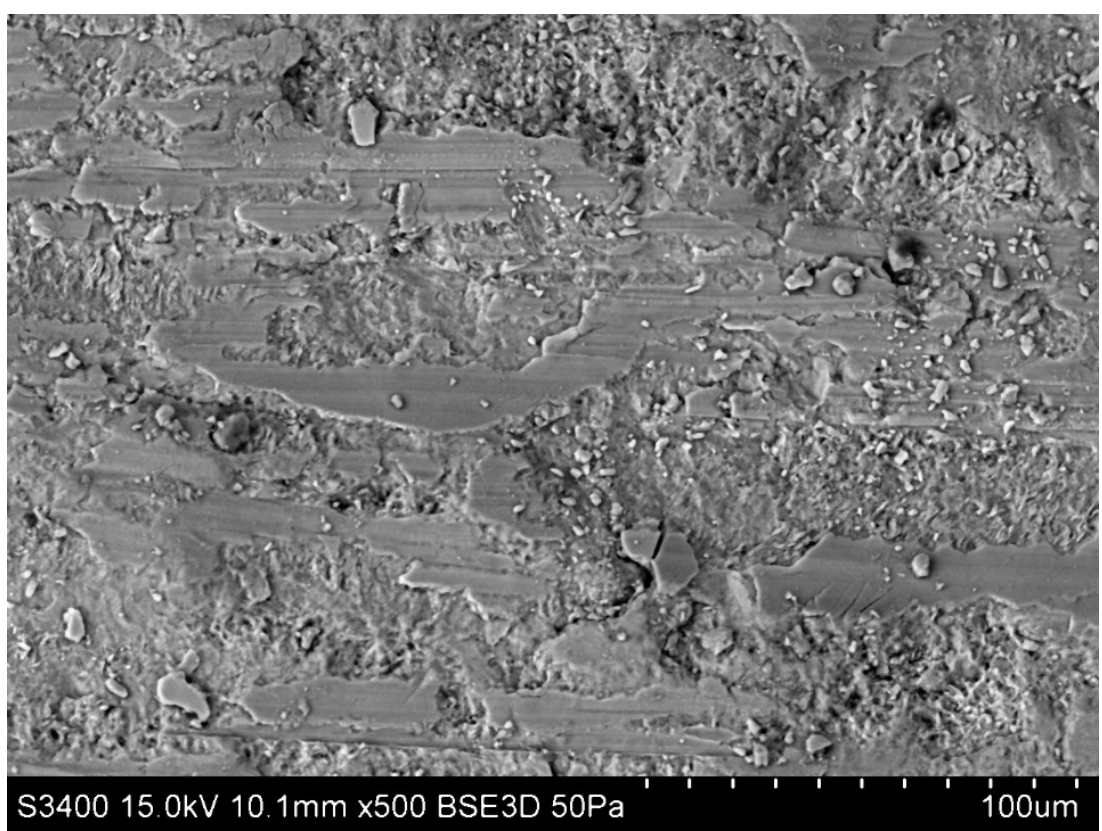

Fig. 3. Image of enamel after drill treatment, magnification 500x 


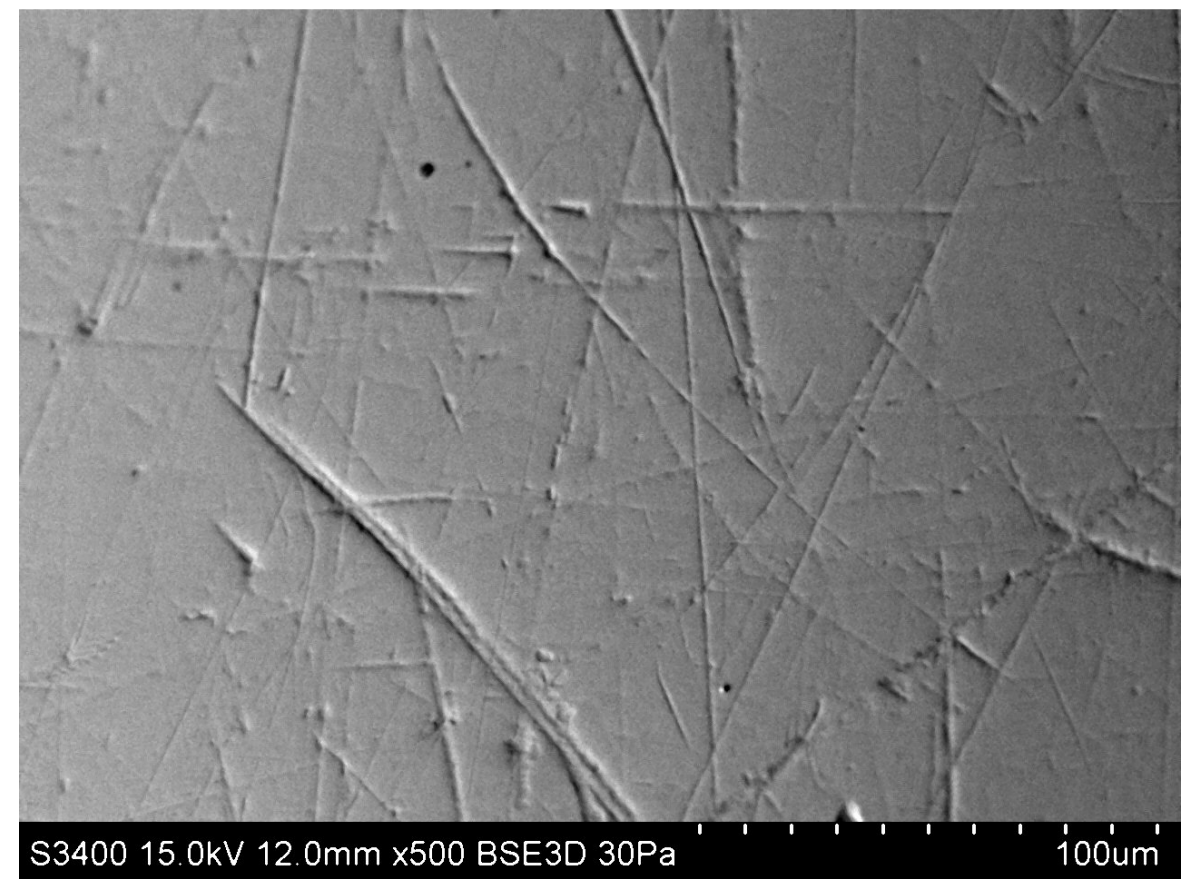

Fig. 4. Image of enamel after laser treatment, magnification 500x

\section{Composite}

Boston's Arkona is a light-curing composite.

Applications of composites is like as [5]: for prosthetic restorations, fillings for all classes of cavities, for bridges and crowns, for the concept of stability rails.

The Boston composite consists of [5]:

- an organic base matrix (bisphenol A diglycidether dimethacrylate, diurethane dimethacrylate, triethylene glycol dimethacrylate)

- inorganic solid fillers (barium-aluminum-silicate glass, fire silica, titanium dioxide)

- additional substances (photoinitiators, inhibitors, digestive, stabilisers, pigment)

\section{Intermediate layer}

Gluma 2 Bond manufactured by Heraus is a light-curing interlayer between enamel and composite.

In dental practice it is used to [6]:fix composite fillings, fix ceramic fillings, and for the treatment of tooth hypersensitivity.

The bond consists of [6]:

- Methacrylate

- Ethanol 
- Photoinitiator

- Glutaraldehyde

- Fillers

\section{Endurance machine}

In the experiment, the INSTRON model 5960 machine, the Instron Bluehill software package and several own components were used.

\section{THE COURSE OF THE EXPERIMENT}

he experiment was carried out in several stages. Initially, the density of the composite was determined, then a vice handle, mechanical elements and silicone moulds were designed and made.

Stages of fixing the composite on enamel:

1. Fixing the teeth in the actyl

Acrylic was prepared by a mixture of self curing powder and a monomer (liquid) according to the following instructions by volume: 3 parts powder and 1 part liquid.

The monomer was poured into the powder and mixed for approximately 30 seconds to obtain a homogeneous consistency. The solution was then poured into a silicone mould. After about 3 minutes, when the consistency was dense enough, a tooth root was placed in it.

2. Preparation of phosphoric acid solution

Before proceeding with direct sample preparation, $100 \mathrm{ml}$ of $37.5 \%$ orthophosphoric acid solution was prepared, by mixing $44 \mathrm{ml}$ of $85 \%$ orthophosphoric acid solution with $56 \mathrm{ml}$ of water.

3. Direct sample preparation

Each sample was prepared by the following steps:

a) The acid was applied to the enamel surface.

b) Waited 20s.

c) The tooth was splashed with water spray for $20 \mathrm{~s}$.

d) The sample was partially dried to reach optimum humidity for the purpose of experiment.

e) Bond layer - intermediate layer was applied, and rubbed for 30s.

f) The sample was blown again.

g) The sample was exposed to a polymerization lamp.

h) The composite was applied to the prepared place.

i) The sample was exposed again.

Samples (Fig. 5) were then suitably placed in a testing machine. 


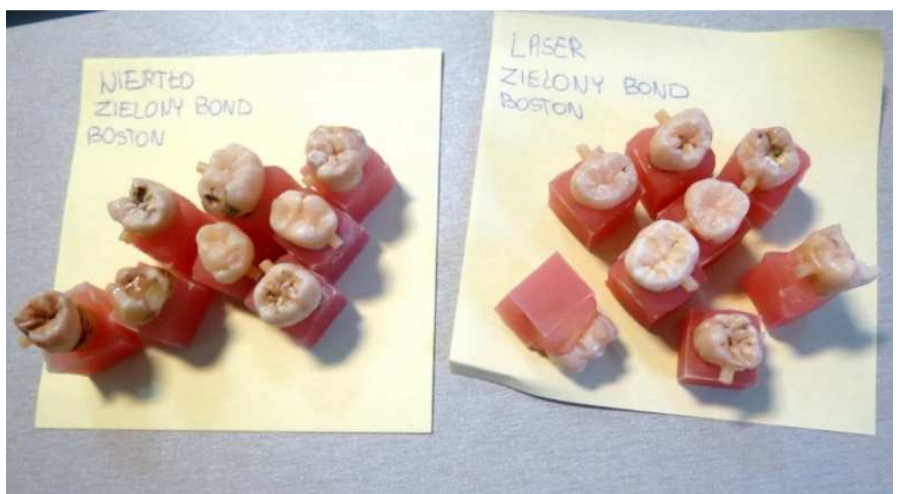

Fig. 5. Samples ready for measurement

4. Measurement of the adhesion force in a strength machine

a) Attaching the sample to the vice handle

A sample was placed in the previously prepared vice handle. The bolt was then tightened with the omni-key to prevent the sample from moving.

b) Placement of a vice handle with a sample into the machine

The next step was the precise placement of the vice handle with the sample in a strength machine. Stable mounting was possible thanks to the pneumatic clamps of the machine.

c) Positioning of the sample

An important aspect was the exact location of the plaque relative to the tooth surface. This allowed the exact measurement of the load at which the sample was broken.

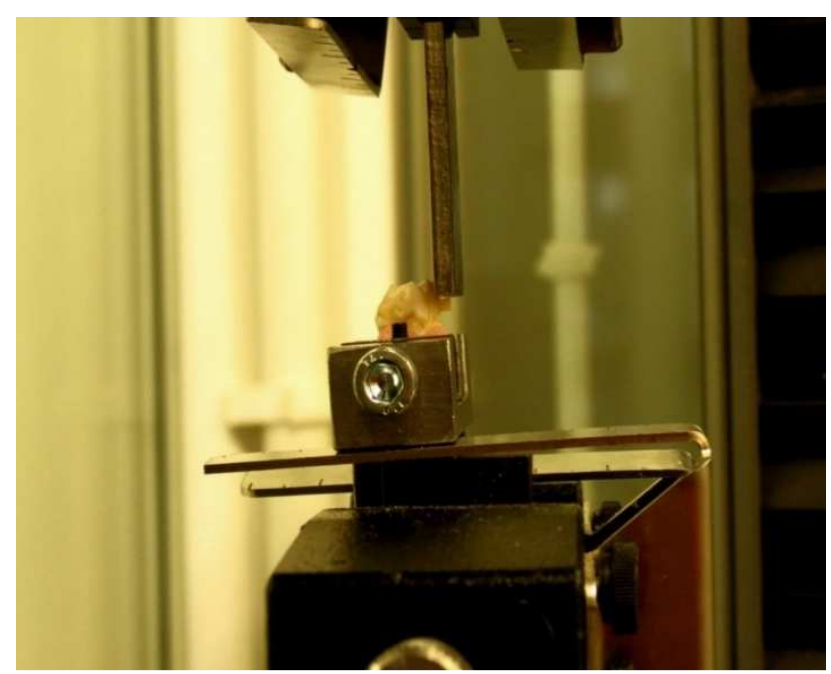

Fig. 6. Sample in the strength machine 


\section{OBSERVATION OF THE DETACHMENT OF THE COMPOSITE}

The plate was moving at a speed of $0.5 \mathrm{~mm} / \mathrm{min}$. By connecting the testing machine with the computer it was possible to follow the course of the experiment on an ongoing basis. The values of forces in the displacement function were observed on the monitor. It was possible to compare the test results with previous samples.

\section{RESULTS OF ADHESION FORCE MEASUREMENTS}

The developed method of measuring the adhesion force turned out to be effective. The presented results have a large discrepancy due to the diverse state of the enamel surface.

\section{Received results}

For each case, the maximum shear stress was calculated according to formula (1).

Table 1. Values for glaze samples without treatment

\begin{tabular}{|c|c|c|c|}
\hline Lp. & Sample label & $\begin{array}{c}\text { Maximum load } \\
\text { F [N] }\end{array}$ & $\begin{array}{c}\text { Maximum tangential stress } \\
\boldsymbol{\tau}_{\max }[\mathbf{M P a}]\end{array}$ \\
\hline 1 & sample_1 & 14,61 & 4,65 \\
\hline 2 & sample_2 & 17,68 & 5,63 \\
\hline 3 & sample_3 & 22,14 & 7,05 \\
\hline 4 & sample_4 & 70,66 & 22,49 \\
\hline 5 & sample_5 & 55,39 & 17,63 \\
\hline 6 & sample_6 & 20,88 & 6,65 \\
\hline 7 & sample_7 & 69,43 & 22,10 \\
\hline 8 & sample_8 & 64,61 & 20,57 \\
\hline Average & & 41,92 & 13,35 \\
\hline Standard deviation & & 25,20 & 8,02 \\
\hline
\end{tabular}

Samples 1 to 8

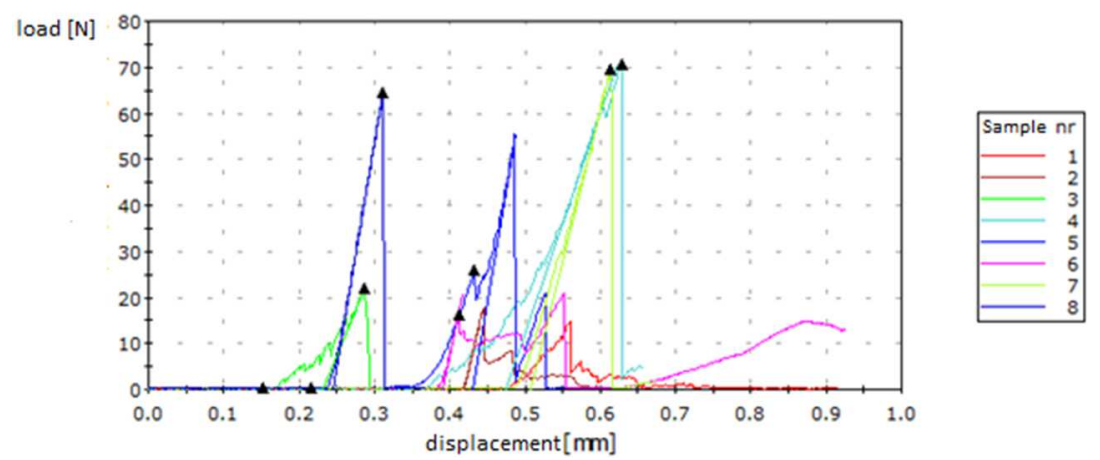

Fig. 7. The dependence of the load on the movement of all glazed specimens without processing 
Average tangential stress maximum with uncertainty for the enamel without treatment:

$$
\tau_{\max _{s r}}=13,4 \pm 8,5 \quad[M P a]
$$

Table 2. Values for glaze specimens after machining with a drill

\begin{tabular}{|c|c|c|c|}
\hline Lp. & Sample label & $\begin{array}{c}\text { Maximum load } \\
\text { F [N] }\end{array}$ & $\begin{array}{c}\text { Maximum tangential stress } \\
\boldsymbol{\tau}_{\mathbf{m a x}}[\mathbf{M P a}]\end{array}$ \\
\hline 1 & sample_1 & 40,20 & 12,80 \\
\hline 2 & sample_2 & 31,50 & 10,03 \\
\hline 3 & sample_3 & 44,50 & 14,16 \\
\hline 4 & sample_4 & 77,83 & 24,77 \\
\hline 5 & sample_5 & 43,32 & 13,79 \\
\hline 6 & sample_6 & 68,49 & 21,80 \\
\hline 7 & sample_7 & 46,20 & 14,71 \\
\hline Average & & 50,29 & 16,01 \\
\hline Standard deviation & & 16,55 & 5,27 \\
\hline
\end{tabular}

Average tangential stress maximum with uncertainty for the enamel after brazing:

$$
\tau_{\max _{\text {sr }}}=16,0 \pm 5,6 \quad[M P a]
$$

\section{Samples 1 to 7}

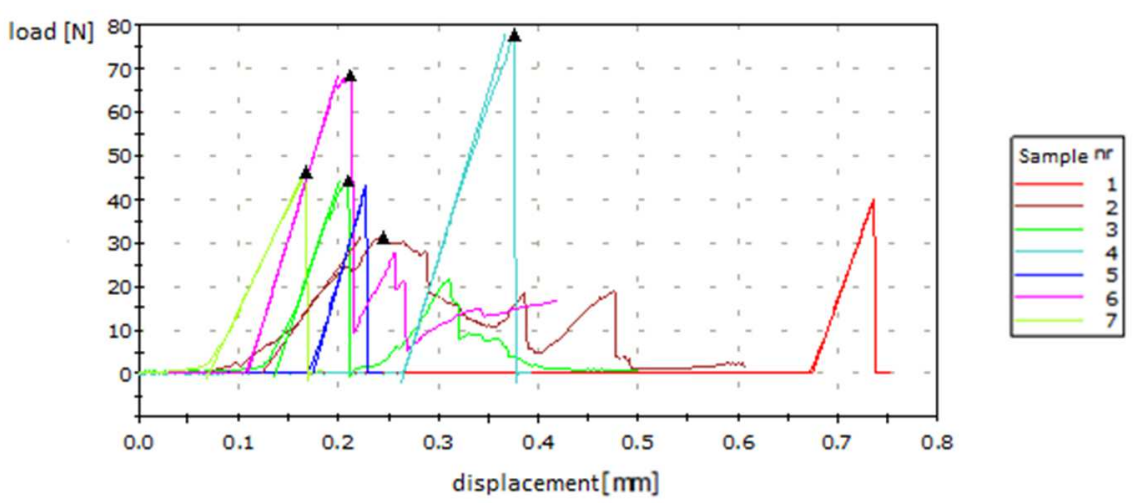

Fig. 8. The dependence of the load on the movement of all samples on the enamel after the treatment with a bit 
Table 3. Values for samples on the surface of the enamel after laser treatment

\begin{tabular}{|c|c|c|c|}
\hline Lp. & Sample label & $\begin{array}{c}\text { Maximum load } \\
\text { F [N] }\end{array}$ & $\begin{array}{c}\text { Maximum tangential stress } \\
\boldsymbol{\tau}_{\mathbf{m a x}}[\mathbf{M P a}]\end{array}$ \\
\hline 1 & sample_1 & 26,51 & 8,44 \\
\hline 2 & sample_2 & 27,59 & 8,78 \\
\hline 3 & sample_3 & 26,92 & 8,57 \\
\hline 4 & sample_4 & 60,34 & 19,21 \\
\hline 5 & sample_5 & 29,17 & 9,28 \\
\hline 6 & sample_6 & 17,07 & 5,43 \\
\hline 7 & sample_7 & 57,66 & 18,35 \\
\hline Average & & 35,04 & 11,15 \\
\hline Standard deviation & & 16,85 & 5,36 \\
\hline
\end{tabular}

Average tangential stress maximum with uncertainty for the enamel after laser treatment:

$$
\tau_{\max _{\mathrm{s} r}}=11,2 \pm 5,7 \quad[\mathrm{MPa}]
$$

Samples 1 to 7
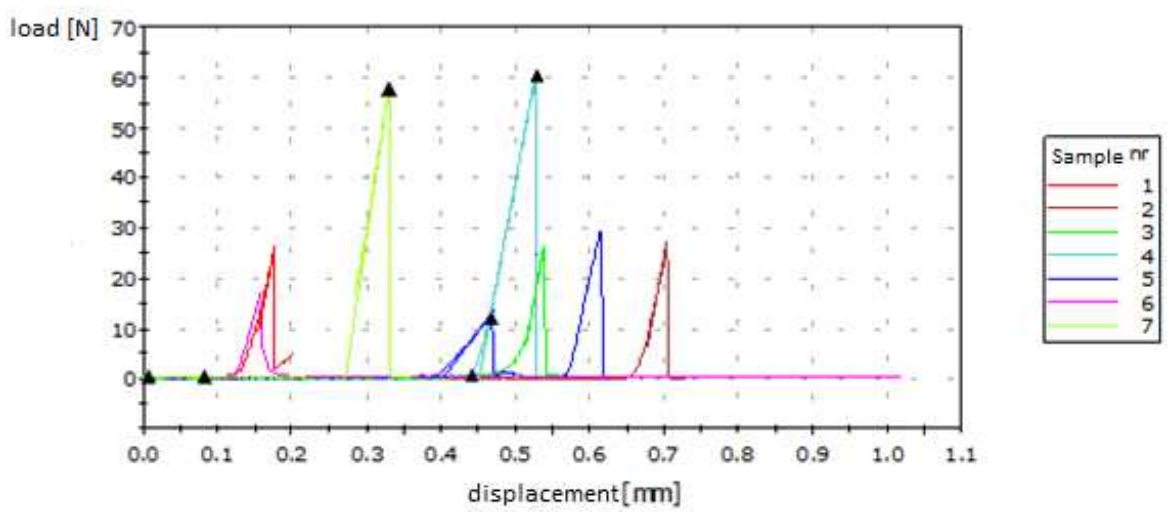

Fig. 9. The dependence of the load on the movement of all samples on the glaze after laser treatment

\section{Development of results}

The maximum stress values for three enamel surface conditions were compared: 


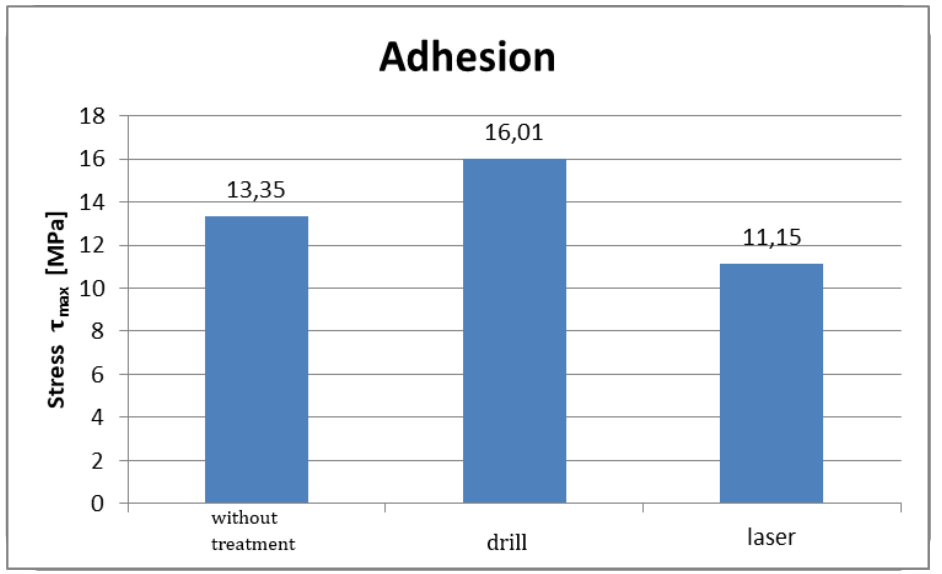

Fig. 10. Adhesion of the enamel composite a) without treatment b) after treatment with a drill, c) after laser treatment

\section{CONCLUSIONS}

1. It has been shown that the tooth surface condition has a significant effect on the adhesion strength of the composite to the enamel.

2. The highest load values were found to be sustained by specimens after machining with a drill (Fig. 10), then glazed specimens without processing, and glaze samples after laser treatment were able to transfer the smallest loads.

3. It can be concluded that the greater the roughness, the stronger the adhesion force in the joint will be.

4. Differences in the strength of adhesion were also caused by differences in the enamel structure, because the elemental composition and hardness depend on genetic conditions and oral hygiene of each person. A significant difference can be seen in the results and the load and displacement graph for the glazefree composites (Fig. 10).

5. The uncertainty of measurements was influenced by errors in the alignment of the sample in the measuring machine. The offset of the composite by a small angle could give completely different results for the shear force. Normal stresses were not included in the experiment.

6. In all the samples, the composite was detached entirely from the enamel surface. Therefore, it is important to properly prepare the surface and use a good quality intermediate layer.

7. The most reproducible results were obtained for samples with enamel after laser treatment, however, due to 2 measurements deviating from the rest, the calculated standard deviation turned out to be greater than the enamel samples after the treatment with a bit. 


\section{REFERENCES}

[1] Herman T.W., Chemia fizyczna, wyd. PZWL, Warszawa 2017.

[2] Awrejcewicz J., Mechanika techniczna i teoretyczna, Wydawnictwo Politechniki Łódzkiej, Łódź 2011, s. 223, 550-551.

[3] Drive S., Wiertta diamentowe w: Prima Classic, Primadental, Kielce 2017.

[4] Demkowska E., Lipski M., Janas A., Lasery w stomatologii, Wydawnictwo Czelej, Lublin 2015, s. 83, 131-132.

[5] Boston - Universal composite curable light with improved mechanical strength, Arkona information leaflet.

[6] Gluma 2 Bond, Heraeus information leaflet.

\section{WPEYW STANU POWIERZCHNI NA ADHEZJE MATERIALU KOMPOZYTOWEGO DO SZKLIWA}

Praca przedstawia metodę pomiaru maksymalnego naprężenia jakie wytrzyma próbka kompozytu umocowana na powierzchni zęba. Badanie przeprowadzono dla 3 różnych stanów powierzchni szkliwa: bez obróbki, po obróbce wiertłem diamentowym oraz po obróbce laserem diodowym. Siłę adhezji zmierzono w maszynie wytrzymałościowej Instron 5960. Wyniki potwierdzają znaczący wpływ stanu powierzchni na adhezję kompozytu do szkliwa.

Słowa kluczowe: maszyna wytrzymałościowa, obróbka zębów, laser, wiertło stomatologiczne.

DOI: 10.7862/rf.2018.pfe.4

Received 4.05.2018

Accepted 15.10.2018 